\title{
HUBUNGAN STATUS GIZI DAN AKTIVITAS OLAHRAGA TERHADAP KEJADIAN DISMENOREA PRIMER PADA REMAJA PUTRI DI SMA WACHID HASYIM 2 TAMAN
}

\author{
Astrida Budiarti \\ Stikes Hang Tuah Surabaya \\ as3da_ns@yahoo.com
}

\begin{abstract}
Abstrak: Remaja putri banyak mengalami dismenorea primer yang dipengaruhi oleh faktor antara lain status gizi dan aktivitas olahraga. Tujuan penelitian ini adalah untuk menganalisis hubungan status gizi dan aktivitas olahraga terhadap dismenorea primer pada remaja putri. Desain observasional analitik melalui pendekatan cross sectional. Populasinya Siswi kelas XI MIPA Intensif SMA Wachid Hasyim 2 Taman yang sudah menstruasi berjumlah 59 orang. Teknik sampling menggunakan simple random sampling dengan sampel 51 responden. Instrumen menggunakan kuesioner. Data dianalisis dengan Uji Korelasi Spearman Rank. Hasil penelitian menunjukkan ada hubungan status gizi dengan kejadian dismenorea primer, nilai $\mathrm{p}=0.001(\mathrm{p}<\alpha=0.05)$, dan ada hubungan antara aktivitas olahraga dengan dismenorea primer, nilai $\mathrm{p}=0.001$ $(\mathrm{p}<\alpha=0.05)$. Oleh karena itu pentingnya edukasi tentang pola makan yang seimbang dengan asupan gizi yang memadai dan olahraga teratur bagi para remaja putri karena dapat mempengaruhi kejadian dismenorea.
\end{abstract}

\section{Kata kunci: Dismenorea primer, status gizi, aktivitas olahraga}

Abstract: Many girls experience primary dysmenorrhoea is affected by factors, including nutritional status and exercise activity. The purpose of this study was to analyze the relationship of nutritional status and sports activity to primary dysmenorrhoea in adolescent girls. This study used analytic observational design with cross sectional approach. The population is the students of class XI Intensive SMA MIPA Wachid Hasyim 2 Park that has experienced menstruation amounted to 59 people. The sampling technique is simple random sampling with 51 respondents. Instruments using questionnaires. Data were analyzed by Spearman Rank Correlation Test. The results showed that there was correlation between nutritional status and primary dysmenorrhoea occurrence, $p=0.001(p<\alpha=0.05)$, and there was a correlation between exercise activity and primary dysmenorrhea, $\mathrm{p}=0.001(\mathrm{p}<\alpha=0.05)$. This study show that the importance of education about a balanced diet with adequate nutritional intake to young women and to regular exercise because it affects the incidence of dysmenorrhoea.

Keywords: Primary dysmenorrhoea, nutritional status, sports activities 


\section{PENDAHULUAN}

Masa remaja pada perempuan dimulai dengan tanda biologis yang menunjukkan keremajaan berupa menstruasi. Menstruasi merupakan hal yang bersifat fisiologis, namun pada kenyataannya banyak perempuan mengalami masalah ketika menstruasi yaitu dismenorea primer (Joseph \& Nugroho, 2010). Remaja yang mengalami dismenorea primer sering terjadi sekitar 2-3 tahun setelah menstruasi pertama (Nugroho \& Utama, 2014). Dismenorea primer disebabkan oleh faktor antara lain menarche dini, riwayat dismenorea pada keluarga, kegemukan serta olahraga (Anurogo \& Wulandari, 2011; Sukarni \& Wahyu, 2013).

Insidens dismenorea menggambarkan lebih dari 50\% perempuan disetiap negara mengalami nyeri menstruasi. Di Amerika sekitar $60 \%$ dan di Swedia sekitar 72\%, sementara di Indonesia diperkirakan $55 \%$ perempuan usia produktif yang tersiksa oleh nyeri selama menstruasi (Priyanti \& Mustikasari, 2014). Hasil penelitian di Sidoarjo menjelaskan bahwa dari 100 orang perempuan usia subur (15-30 tahun) 71\% diantaranya mengalami dismenorea (Novia \& Puspitasari, 2008). Hasil studi pendahuluan tanggal 2 Februari 2016 pada siswi kelas XI MIPA Intensif di SMA Wachid Hasyim 2 Taman ditemukan dari 23 siswi terdapat 20 siswi yaitu sekitar $87 \%$ yang mengalami dismenorea.

Nyeri pada dismenorea primer berasal dari peningkatan kadar prostaglandin yang menimbulkan peningkatan kontraksi uterus yang berlebihan (Anurogo \& Wulandari, 2011). Perbedaan beratnya nyeri saat dismenorea tergantung pada kadar prostaglandin. Perempuan yang mengalami dismenorea memiliki kadar prostaglandin 5-13 kali lebih tinggi dibandingkan dengan yang tidak mengalami dismenorea (Sukarni \& Wahyu, 2013). Sensasi nyeri dismenorea diperkuat ketika bekuan atau potongan jaringan tubuh dari lapisan kandungan melalui leher rahim, terutama jika leher rahimnya sempit (Sukarni \& Margareth, 2013). Semua perempuan yang dismenorea mengalami rasa tidak enak diperut bagian bawah sebelum dan selama menstruasi dan sering kali mual pada dismenorea kategori berat sehingga harus istirahat dan meninggalkan pekerjaan sehari-hari dalam beberapa jam atau hari (Sukarni \& Wahyu, 2013).

Pengobatan dismenorea dengan obat anti peradangan non-steroid. Rasa nyeri dapat dikurangi dengan istirahat yang cukup, olah raga yang teratur terutama berjalan, pemijatan, yoga, dan kompres hangat di daerah perut (Nugroho \& Utama, 2014). Dismenorea tidak boleh dibiarkan karena menurunkan produktivitas perempuan, oleh karena itu perempuan harus memahami penanganan dismenorea dan mengetahui faktor yang menyebabkan dismenorea.

Tujuan penelitian ini adalah menganalisis hubungan antara status gizi dan aktivitas olahraga dengan kejadian dismenorea primer pada remaja putri.

\section{METODE}

Penelitian ini menggunakan desain uji korelasi spearman rank test. Populasinya adalah Siswi Kelas XI MIPA Intensif SMA Wachid Hasyim 2 Taman yang sudah menstruasi berjumlah 59 orang. Sampel berjumlah 
51 orang yang memenuhi kriteria inklusi. Teknik sampling secara probability sampling menggunakan simple random sampling. Penelitian dilaksanakan pada tanggal 10-13 Juni 2017. Uji statistik yang digunakan adalah uji korelasi spearman rank test. Instrumen pengumpulan data menggunakan lembar observasi Numeric Rating Scale (NRS) dengan rentang skala 0-10 untuk mengetahui tingkat nyeri menstruasi dengan Nilai 0 : Tidak nyeri, 1: Nyeri ringan (skala 1-3), 2: Nyeri sedang (skala 4-6), 3: Nyeri hebat (skala 7-9), 4: Nyeri yang tak tertahankan (skala 10).

\section{HASIL DAN PEMBAHASAN Hasil penelitian}

1. Distribusi Responden Berdasarkan Status Gizi

\begin{tabular}{|c|c|c|}
\hline Status Gizi & $\begin{array}{l}\text { Frekuensi } \\
\text { (f) }\end{array}$ & $\begin{array}{c}\text { Persentase } \\
(\%)\end{array}$ \\
\hline Underweight & 10 & 19,6 \\
\hline Normal & 30 & 58,8 \\
\hline Overweight & 11 & 21,6 \\
\hline Total & 51 & 100 \\
\hline \multicolumn{3}{|c|}{$\begin{array}{l}\text { Tabel menunjukkan sebagian besar } 58,8 \\
\% \text { responden memiliki status gizi yang } \\
\text { normal. } \\
\text { 2. Distribusi Responden Berdasarkan } \\
\quad \text { Frekuensi Olahraga } \\
\end{array}$} \\
\hline Olahraga & $\begin{array}{l}\text { Frekuensi } \\
\text { (f) }\end{array}$ & $\begin{array}{c}\text { Persentase } \\
(\%)\end{array}$ \\
\hline Kurang & 44 & 86 \\
\hline Baik & 7 & 14 \\
\hline Total & 51 & 100 \\
\hline
\end{tabular}

Tabel menunjukkan mayoritas $86 \%$ responden kurang dalam melakukan olahraga, dan hanya $14 \%$ yang memiliki frekuensi olahraga yang baik.

3. Distribusi Responden Berdasarkan Dismenorhea

\begin{tabular}{ccc}
\hline Dismenorhea & $\begin{array}{c}\text { Frekuensi } \\
\text { (f) }\end{array}$ & $\begin{array}{c}\text { Persentase } \\
(\%)\end{array}$ \\
Tidak nyeri & 6 & 11,8 \\
Nyeri ringan & 18 & 35,3 \\
Nyeri sedang & 26 & 51.0 \\
Nyeri Berat & 1 & 1,9 \\
Total & 51 & 100
\end{tabular}

Tabel menunjukkan 51\% responden berada pada dismenorea tinggak sedang, dan paling sedikit 1,9\% mengalami nyeri berat.

4. Hubungan Status Gizi Terhadap Dismenorea Primer Pada Remaja Putri Di SMAWachid Hasyim 2 Taman

\begin{tabular}{|c|c|c|c|c|c|c|c|c|c|c|}
\hline \multirow{3}{*}{$\begin{array}{c}\text { Status } \\
\text { Gizi }\end{array}$} & \multicolumn{10}{|c|}{ Dismenorhea } \\
\hline & \multicolumn{2}{|c|}{$\begin{array}{l}\text { Tidak } \\
\text { Nyeri }\end{array}$} & \multicolumn{2}{|c|}{$\begin{array}{l}\text { Nyeri } \\
\text { Ringan }\end{array}$} & \multicolumn{2}{|c|}{$\begin{array}{l}\text { Nyeri } \\
\text { Sedang }\end{array}$} & \multicolumn{2}{|c|}{$\begin{array}{l}\text { Nyeri } \\
\text { Berat }\end{array}$} & \multicolumn{2}{|c|}{ Total } \\
\hline & $\mathrm{F}$ & $\%$ & $\mathrm{~F}$ & $\%$ & $\mathrm{~F}$ & $\%$ & $\mathrm{~F}$ & $\%$ & f & $\%$ \\
\hline $\begin{array}{l}\text { Unde } \\
\text { rweig } \\
\text { ht }\end{array}$ & 3 & 8,8 & 7 & $\begin{array}{l}20 \\
, 6\end{array}$ & 23 & $\begin{array}{l}67 \\
, 6\end{array}$ & 1 & $\begin{array}{l}2, \\
9\end{array}$ & 34 & $\begin{array}{l}10 \\
0\end{array}$ \\
\hline $\begin{array}{l}\text { Norm } \\
\text { al }\end{array}$ & 3 & 20 & 9 & 60 & 3 & 20 & 0 & 0 & 15 & $\begin{array}{l}10 \\
0\end{array}$ \\
\hline $\begin{array}{c}\text { Over } \\
\text { weigh } \\
t\end{array}$ & 0 & 0 & 2 & $\begin{array}{l}10 \\
0\end{array}$ & 0 & 0 & 0 & 0 & 2 & $\begin{array}{l}10 \\
0\end{array}$ \\
\hline Total & 6 & 11,8 & 18 & $\begin{array}{l}35 \\
, 3\end{array}$ & 26 & $\begin{array}{l}51 \\
, 0\end{array}$ & 1 & $\begin{array}{l}2, \\
9\end{array}$ & 51 & $\begin{array}{l}10 \\
0\end{array}$ \\
\hline & & Uji & & spe & 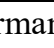 & & & & & \\
\hline
\end{tabular}

Tabel menunjukkan hasil uji statistik Sperman Rank dengan hasil $\mathrm{p}<0,05$. Hal ini menunjukkan bahwa terdapat hubungan antara 
status gizi dengan kejadian dysmenorhea.

5. Hubungan Frekuensi Olahraga Terhadap Dismenorea Primer Pada Remaja Putri Di SMAWachid Hasyim 2 Taman

\begin{tabular}{|c|c|c|c|c|c|c|c|c|c|c|}
\hline \multirow{3}{*}{$\begin{array}{l}\text { Frek } \\
\text { uensi } \\
\text { Olah } \\
\text { raga }\end{array}$} & \multicolumn{10}{|c|}{ Dismenorhea } \\
\hline & \multicolumn{2}{|c|}{$\begin{array}{l}\text { Tidak } \\
\text { Nyeri }\end{array}$} & \multicolumn{2}{|c|}{$\begin{array}{l}\text { Nyeri } \\
\text { Ringan }\end{array}$} & \multicolumn{2}{|c|}{$\begin{array}{l}\text { Nyeri } \\
\text { Sedang }\end{array}$} & \multicolumn{2}{|c|}{$\begin{array}{l}\text { Nyeri } \\
\text { Berat }\end{array}$} & \multicolumn{2}{|c|}{ Total } \\
\hline & $\mathrm{F}$ & $\%$ & $\mathrm{~F}$ & $\%$ & $\mathrm{~F}$ & $\%$ & F & $\%$ & $\mathrm{f}$ & $\%$ \\
\hline $\begin{array}{l}\text { Kura } \\
\text { ng }\end{array}$ & 3 & 8,8 & 9 & 20,6 & 23 & $\begin{array}{l}6 \\
7, \\
6\end{array}$ & 1 & 2,9 & 36 & 100 \\
\hline Baik & 3 & 20 & 9 & 60 & 3 & $\begin{array}{l}2 \\
0\end{array}$ & 0 & 0 & 15 & 100 \\
\hline Total & 6 & 11,8 & 18 & 35,3 & 26 & $\begin{array}{l}5 \\
1, \\
0\end{array}$ & 1 & 2,9 & 51 & 100 \\
\hline & & & & & & & & & & \\
\hline
\end{tabular}

Tabel menunjukkan hasil uji statistik Sperman Rank dengan hasil $\mathrm{p}<$ 0,05 . Hal ini menunjukkan bahwa terdapat hubungan antara Aktivitas olahraga dengan kejadian dysmenorhea. Dimana remaja yang frekuensi olahraganya dalam kategori baik sedikit yang mengalami nyeri.

\section{Pembahasan}

1. Hubungan Status Gizi Terhadap Dismenorhea Primer Pada Remaja Putri Di SMA Wachid Hasyim 2 Taman

Hasil penelitian menunjukkan bahwa terdapat hubungan antara status gizi dengan kejadian dismenorhea primer pada remaja putri di SMA Wahcid Hasyim 2 taman. Faktor yang mempengaruhi usia menarche salah satunya status gizi disamping faktor lain seperti rangsangan audio visual, ras (Sukarni \& Margareth, 2013). Status gizi tersebut dapat diukur dengan metode yang murah, mudah, dan sederhana yaitu dengan menggunakan IMT (Pradana,2014:10). Menurut Batubara (2010 dalam Lasandang, 2016:5) responden dengan status gizi gemuk menyebabkan usia menarche menjadi cepat karena estrogen yang disimpan pada jaringan lemak dapat meningkatkan bioaktifitas. Siswi tersebut termasuk dalam status gizi gemuk, sehingga sesuai dengan teori bahwa status gizi gemuk dapat mempercepat usia menarche.

Hasil penelitian ini sejalan dengan penelitian yang dilakukan oleh Munda (2012) di SD dan SMP Katolik Santa Theresia Malalayang Kota Manado, menunjukkan bahwa responden yang mempunyai status gizi overweight mengalami usia menarche lebih cepat sebanyak $51.6 \%$, dengan nilai $\mathrm{p}=$ 0.000 , dan terdapat hubungan bermakna antara indeks massa tubuh dengan usia menarche. Beberapa terapi bisa diberikan untuk mengurangi nyeri dysmenorhea salah satunya terapi pemberian susu kedelai. Hal ini sejalan dengan hasil penelitian yang dilaksanakan Budiarti, A \& Wulandari, R.N (2015) yang menyatakan bahwa terapi susu kedelei efektif untuk mengurangi nyeri dysmenorhea.

2. Hubungan Frekuensi Olahraga Terhadap Dismenorhea Primer Pada Remaja Putri Di SMA Wachid Hasyim 2 Taman

Hasil penelitian menunjukkan bahwa terdapat hubungan antara frekuensi olahraga dengan kejadian dismenorhea primer pada remaja putri di SMA Wahcid Hasyim 2 taman. Menurut Tjokronegoro (2014 dalam Cholifah, 2015:41) kejadian dismenorea akan meningkat dengan kurangnya olahraga, sehingga ketika terjadi dismenorea oksigen tidak dapat tersalurkan ke pembuluh darah yang saat ini mengalami vasokonstriksi sehingga menimbulkan timbulnya rasa nyeri. 
Apabila seseorang teratur melakukan olahraga maka dapat menyediakan oksigen hampir 2 kali lipat per menit sehingga oksigen tersampaikan pada pembuluh darah yang mengalami vasokonstriksi. Penelitian ini menunjukkan bahwa responden yang melakukan olah raga 1 minggu 1 kali mengalami dismenorea dengan skala nyeri sedang karena kurangnya melakukan olah raga sehingga oksigen tidak dapat tersalurkan ke pembuluh darah saat vasokonstriksi, sedangkan pada responden yang melakukan olah raga 1 minggu 3 kali namun masih mengalami dismenorea dengan skala nyeri sedang dipengaruhi oleh faktor usia menarche, stres, dan indeks massa tubuh sesuai dengan hasil penelitian sebelumnya (Anurogo dan Wulandari, 2011:55); (Sukarni dan Wahyu, 2013:41).

\section{KESIMPULAN}

Kesimpulan penelitian ini menunjukkan terdapat hubungan antara status gizi dan aktivitas olahraga dengan kejadian dismenorea primer.

Hasil penelitian ini merekomendasikan pentingnya edukasi bagi para remaja putri tentang pola makan yang seimbang dengan asupan gizi yang memadai serta olahraga teratur.

\section{DAFTAR PUSTAKA}

Anurogo, Dito dan Wulandari, Ari. (2011). Cara Jitu Mengatasi Nyeri Haid. Yogyakarta: ANDI.

Budiarti, A \& Wulandari, R.N (2015). Efektivitas Pemberian Susu Kedelai Terhadap Penurunan Skala Nyeri Haid (Dis menorea) Pada Remaja Putri Di Pondok Pesantren Al-Jihad Surabaya. Jurnal Ilmiah Keperawatan Vol. 1 No.1/Oktober 2015. url. http://ejournal- stikeshangtuahsurabaya.ac.id/index.php/ jik/article/viewFile/28/33

Cholifah, Alfinda Ayu Hardikasari. (2015). Hubungan Anemia, Status Gizi, Olahraga dan Pengetahuan dengan Kejadian Dismenorea pada Remaja Putri. Jurnal Midwiferia, 1 (1) April, pp. 1.

Joseph dan Nugroho, S. M. (2010). Catatan Kuliah: Ginekologi dan Obstetri (OBSGYN). Yogyakarta: Nuha Medika.

Mansur, Herawati dan Budiarti, Temu. (2014). Psikologi Ibu dan Anak untuk Kebidanan. Jakarta: Salemba Medika.

Mubarak, Wahid Iqbal; Indrawati, Lilis dan Susanto, Joko. (2015). Buku Ajar Ilmu Keperawatan Dasar Buku 1. Jakarta: Salemba Medika.

Novia, Ika dan Puspitasari, Nunik. (2008). Faktor Risiko yang Mempengaruhi Kejadian Dismenorea Primer. The Indonesian Journal of Public Health, 4 (2) Maret, pp. 101.

Nugroho, Taufan. (2012). OBSGYN: Obstetri dan Ginekologi untuk Kebidanan dan Keperawatan. Yogyakarta: Nuha Medika.

Nugroho, Taufan dan Utama, Bobby Indra. (2014). Masalah Kesehatan Reproduksi Wanita. Yogyakarta: Nuha Medika.

Priyanti, Sari dan Mustikasari, Anggraeni Devi. (2014). Hubungan Tingkat Stres Terhadap Dismenorea pada Remaja Putri di Madrasah Aliyah Mamba'ul Ulum Awang-Awang Mojosari Mojokerto. Jurnal Ilmiah Kesehatan Politeknik Kesehatan Majapahit, 6 (2) November, pp. 1. 
Sukarni, Icemi dan Wahyu. (2013). Buku Ajar: Keperawatan Maternitas. Yogyakarta: Nuha Medika.

Sukarni, Icesmi dan Margareth. (2013). Kehamilan, Persalinan, dan Nifas: Dilengkapi dengan Patologi. Yogyakarta: Nuha Medika. 